\title{
The Impact of Brand Equity on Conversion Behavior in the Use of Personal Banking Services: Case Study of Commercial Banks in Vietnam
}

Thi Thu Cuc Nguyen

check for

updates

Citation: Nguyen, Thi Thu Cuc. 2021. The Impact of Brand Equity on Conversion Behavior in the Use of Personal Banking Services: Case Study of Commercial Banks in Vietnam. Journal of Risk and Financial Management 14: 346. https:// doi.org/10.3390/jrfm14080346

Academic Editor: Eleftherios I. Thalassinos

Received: 19 June 2021

Accepted: 21 July 2021

Published: 28 July 2021

Publisher's Note: MDPI stays neutral with regard to jurisdictional claims in published maps and institutional affiliations.

Copyright: (c) 2021 by the author Licensee MDPI, Basel, Switzerland. This article is an open access article distributed under the terms and conditions of the Creative Commons Attribution (CC BY) license (https:// creativecommons.org/licenses/by/ $4.0 /)$
Faculty of Economics, Vinh University, Vinh City 43100, Vietnam; cucntt@vinhuni.edu.vn

\begin{abstract}
The brand equity of banks plays a crucial role in determining customer behavior of using their services. The study aims to examine the impact of brand equity on conversion behavior in the use of personal banking services at commercial banks in Vietnam. The paper uses quantitative research methods, through linear SEM (Structural Equation Modelling) analysis, with survey data including 554 samples of individual customers of commercial banks. The study's findings show that the bank's brand equity has a negative impact on the behavior of individual customers. In the relationship between these two factors, competitive advertising effectiveness and loyalty of customers act as intermediary factors. On that basis, the study makes a number of recommendations to preclude customers leaving and minimize business losses caused by the conversion of customers' banks. The findings of this study have shown the importance and impact of brand equity on conversion behavior in the use of personal customer services. These are meaningful contributions both theoretically and practically to help banks get a deeper insight into brand equity and the need to pay attention to building and developing sustainable brand equity for the bank, as well as an important basis for further research.
\end{abstract}

Keywords: brand equity; competitive advertising effectiveness; loyalty; opportunistic behaviors; conversion behavior

\section{Introduction}

In the current competitive environment, the client is the decisive factor for the existence of the banks. Competition in business operations requires commercial banks to adjust their business strategies, focus on individual customer segments, adjust income structures, and control risks toward safety and efficiency goals. In the banking industry, conversion behavior means the change of customers in the process of changing from the use of one bank's services to another (Garland 2002). According to Boote (1998), Bolton and Bronkhurst (1995), a customer's decision to stop shopping for a particular service or stop using a certain company's services. The studies of Keaveney and Parthasarathy (2001), Reichheld (1996) shows that customer's conversion behavior reduces the income and profits of companies because the company has paid the initial and other costs to attract a new customer. The fierce competition in the banking industry has caused conversion behavior to have a significant impact on the reduction of market share and profitability of banks (Ennew and Binks 1996).

A bank's brand can be understood as a term used in marketing activities, representing the transaction name of a bank, associated with its own identity and reputation, the image of the subject bearing this name in order to make a deep impression to customers and distinguish it from other banks in its monetary-credit business and provision of banking services. Branding is about increasing brand equity (Yoo and Donthu 2001). Brand popularity and origin image affect brand loyalty, brand awareness, perceived quality, and brand equity (Filieri et al. 2019). Consumers develop feelings, associations with the brand and become loyal to the brand because of the values that the brand brings to them. Brand 
equity is consumer-based, rests on the idea that the power of a brand lies in the mind of the consumer (Leone et al. 2006). Relevant and high stature brands also get higher promotion and advertising response though they benefit less from increased distribution. Differentiated brands only get better advertising response (Datta et al. 2017).

Up to now, in their research works, many authors have mentioned the relationship between brand equity and conversion behavior in service use of individual customers at commercial banks. Zeithaml et al. (1996) found that customers tend to switch the use of services of banks if a bank's performance deteriorates. Moreover, when customers decide not to use the service of a bank, they can slander the reputation and image of the bank by word of mouth. In the financial services industry, a good reputation can increase customer confidence when conducting transactions and allow customers to better visualize and understand products when they do not already own them (Berry 2000). Camerer and Weigelt (1988) indicate that a good reputation serves as an important strategic tool used by firms to earn above-average returns. For the banking industry, Wang et al. (2003) suggest that the bank's reputation plays a crucial role in determining customer behavior of using the service. Similarly, studies of Javalgi et al. (1989) demonstrate that customer decisions can be influenced by the bank's brand. A good brand can strengthen customers' trust in a bank, while a bad brand can increase a customer's decision to switch banks. The study by Gerrard and Cunningham (2004) concluded that the brand equity of a bank is one of the factors that makes customers decide to switch to using services and the brand is considered to be the integrity of the bank and the financial stability of a bank. Barr (2009) also say that a bank's brand has a strong influence on customer choice. When a brand connects with the self-image of customers, it enhances their perception toward the brand and increases their level of satisfaction. It would, thus, create a psychological attachment to the brand and thereby build loyalty (Rambocas et al. 2018).

In fact, in Vietnam, most commercial banks in recent years have achieved quite high business performance and show positive trend of promising development. The scale of operations is growing, accompanied by a significantly improved technical efficiency. In particular, the efficiency of commercial banks' operation scale is better than the technical efficiency. In addition, banks face high competitive pressure both domestically and internationally, while the management activities at some banks are not really professional and effective, leading to many products and services for customers. The personalization of the banks' current supply is inadequate, not satisfying the needs of customers. The types of services provided to customers are not diverse. In addition, the facilities of most commercial banks, although well-equipped, are inadequate, and modern payment devices are not available, so they cannot satisfy the needs of customers. Some services such as card services, insurance services have relatively few accompanying utilities, so they cannot satisfy customers. Promotion activities such as product and service packages are still limited, so many customers do not know about the bank's services. These issues show the importance of the process of improving efficiency in competitive advertising in order to increase the bank's brand and reputation, maintain customer engagement with products and services, and limit conversion behavior in service use of individual customers at commercial banks.

The study aims to build a model and test the direct and indirect relationships of brand equity to conversion behavior in service use of individual customers at commercial banks in Vietnam. There is a direct and positive impact of brand equity on the conversion behavior in using services of individual customers at retail commercial banks in Vietnam or not? Whether the factors namely Competitive advertising effectiveness; Opportunistic behaviors and Loyalty play a mediating role in the relationship between brand equity and individual customer conversion behavior. In the body, on the basis of literature review and related research works, the article proposes a research model, and check it through SEM linear structural model analysis. The findings of this study show both theoretical and practical contributions when demonstrating the importance and impact of brand equity on conversion behavior in individual customers' use of services and the roles as mediating 
factors such as competitive advertising effectiveness and customer loyalty. From there, the research proposes some recommendations to limit customers' behaviors of changing services and other personal services for commercial banks.

\section{Literature Reviews and Hypotheses}

\subsection{Literature Review}

Brand equity is a core concept in brand management (Merrilees 2017), the replication and extension of the branding concept took a path which emerged from product brands to nation brands (Kashif et al. 2015). Aaker (1991) defines brand equity as a set of assets and liabilities associated with a brand, its name and logo, plus or minus the value provided by a product or service for a company or its customers. He believes that brand equity includes five components, which are: brand loyalty, brand awareness, perceived quality, brand associations, and other brand assets. According to Keller (1998), brand equity includes: brand awareness, brand image, reaction to the brand, and brand relationship. According to Yoo et al. (2000), brand equity as the difference in consumer choice between the focal branded product and an unbranded product given the same level of product features.

Conversion behavior is seen as the customer's abandonment of the service (Stewart 1998). According to Garland (2002), customer conversion behavior is the behavior of abandoning the current service provider and adopting another service provider and conversion behavior has become a focus of research in the service field. Customer service behavior is prone to change when financial products are purchased with almost identical requirements offered by different commercial banks (Beckett et al. 2000). Research by Zhang et al. (2009) shows that price, reputation, service quality, effective advertising, unwilling to change services, distance, and switching costs affect the decision to switch banks. When customers switch banks because the bank does not meet their expectations, most of them stop paying attention to the previous bank that they used.

Besides the two main factors mentioned, brand equity and conversion behavior in individual customers' use of services, the study also mentions the mediating factors in the model including competitive advertising effectiveness, opportunistic behaviors, and loyalty of customers. Cengiz et al. (2007) argue that the competitive advertising of banks is the activities conducted to increase sales or promote the image of a service, financial institution, or other business activities. The basic purposes of advertising are to provide product and service features to potential customers. Research by Rust et al. (1996) shows that advertising helps to promote the useability of customers during the growth phase of the bank as well as increase the opportunity for customers to understand more about the characteristics of the services and business processes.

Morgan and Hunt (1994) argue that the essence of opportunistic behaviors is the breaking of commitments, violations of obligations, and responsibilities that require performance. Opportunistic behaviors are considered as negative behaviors of employees in the organization, governed, and determined by the employees' perceptions, attitudes, and abilities (Nguyen et al. 2020). Both ethical leadership and formal control systems individually play significant roles in reducing employee opportunistic behavior (Ko et al. 2018).

The initial conceptualizations of customer loyalty that focused on merely the behavioral perspective made it difficult to differentiate true loyalty from spurious loyalty (Boateng 2019). According to Duncan and Elliot (2002), customer loyalty is an important factor contributing to the income and profit of a business. Loyal customers often establish a more stable relationship with the business than disloyal customers. In essence, loyalty is a genuine commitment to consistently repurchase or reutilize a certain product or service in the future (Suhartanto et al. 2018). Research by Chaudhuri (1999) suggests that customers are considered loyal to a brand when they tend to buy and use a lot of products of that brand. With banks, customer loyalty shows that when customers have chosen to do business with a bank, they will continue to do business with that bank, they will encourage others to use the bank's services and when there is a need of other services, they will consider banking as the first choice (Khirallah 2005). As the demand for a more sustain- 
able society increases, adopting a sustainable banking approach serves as a competitive advantage for banks that are focused on attaining bank loyalty (Igbudu et al. 2018).

\subsection{Hypothesis}

\subsubsection{Brand Equity and Conversion Behavior in Service Use}

Improving brand equity is always a goal that banks aim to not only affirm the domestic brand, but also expect to be able to compete in regional and international markets. A good brand will help the quality of products and services increase competitiveness and lower costs, thereby increasing the ability to attract and retain customers (Wang et al. 2003). Brand equity is also likely to influence customer satisfaction due to the differential advantage that it provides which results from elevated customer evaluations, brand awareness, perceived quality, and brand association (Rambocas et al. 2018). In the context of globalization, competition between banks is getting wider and fiercer; brands are the passports of banks to continue to stand firmly in the worldwide market. The strength and position of the brand closely associated with the business strategy plays an important role in creating a difference, increasing competitiveness and prestige for banks. Improving brand equity will have a positive impact on customer psychology, helping customers feel more secure and confident in using the bank's services. From there, creating a commitment and long-term attachment of customers to the bank, limiting customers to switching banks and personal services for commercial banks. In the context of commercial banks in Vietnam, in order to test the impact relationship of brand equity on conversion behavior of individual customers, the study hypothesized (see Figure 1):

Hypothesis 1 (H1). Brand equity has a negative effect on conversion behavior in service use of individual customers at commercial banks in Vietnam.

\subsubsection{Brand Equity and Competitive Advertising Effectiveness}

According to Barney (1991), brand equity brings competitiveness to the company, strongly influences the evaluation of services, helps to increase profits in the future, closely linked with the demand for goods and services from customers. Brand attachment and brand attitude partially mediate the relationship between image and brand equity (Ansary and Hashim 2018). Good branding plays an important role in sending positive signals about the bank's reliability and competence to the public (Vendelo 1998). The bank is always interested in improving brand equity and accelerating sustainable relationships with organizations and individuals to create long-term and effective competitive benefits and values for the bank. In order to clarify the relationship between brand equity and competitive advertising effectiveness of commercial banks, the author hypothesizes:

Hypothesis 2 (H2). Brand equity has a positive impact on competitive advertising effectiveness of commercial banks in Vietnam.

\subsubsection{Competitive Advertising Effectiveness and Conversion Behavior in Service Use}

Chakravarty et al. (2004) said that if a bank's competitiveness is reduced in combination with the similarity of products and services, it can easily affect customer conversion behavior. Consumer reactions to advertising messages through multiple channels were strong predictors of purchase propensity (Klapdor et al. 2015). Davies (1996) argues that advertising can strengthen the connection between organizations and customers and in particular will help reduce customer anxieties. According to Cengiz et al. (2007), the effectiveness of advertising can promote loyalty and retain customers for commercial banks. When customers can afford nearly all the same financial products and services offered by retail banks, customers are also inclined to change their banking behavior (Beckett et al. 2000). However, Balmer and Stovig (1997) argues that advertising can strengthen financial services but not make a difference. Advertising activities about banking products and services, when promoting their effectiveness, will contribute to helping customers to achieve mental 
security, increasing cohesion and reducing conversion behaviors in using services. In the context of commercial banks in Vietnam, in order to examine the impact of competitive advertising effectiveness on conversion behavior in service use by individual customers, the following hypothesis is proposed:

Hypothesis 3 (H3). Competitive advertising effectiveness has a negative impact on conversion behavior in service use of individual customers at commercial banks in Vietnam.

\subsubsection{Brand Equity and Opportunistic Behaviors}

The bank's brand is associated with its own identity, reputation, and image in order to make a deep impression on customers and distinguish it from other organizations in business activities. Brand equity brings expectations to customers about the positive attitude, professional behavior of bank staff towards them. Karatepe et al. (2019) recognize that the attitudes and behaviors of frontline bank employees influence the firm's performance because employees serve as a critical link between the organization and its customers by responding to customer requests successfully or providing fair solutions to customer problem. Customers who experience services at banks that they trust in terms of prestige, values and built image will feel more secure, psychologically comfortable, and confident to help customers make decisions and make the right decision in choosing banking services. Thereby, minimizing inappropriate personal motives to benefit themselves from customers. To clarify the relationship between bank brand equity and opportunistic behaviors of individual customers in using the service, the following hypothesis is proposed:

Hypothesis 4 (H4). Bank brand equity has a negative effect on opportunistic behaviors of individual customers at commercial banks in Vietnam.

\subsubsection{Opportunistic Behaviors and Conversion Behaviors in Service Use}

Research by Ramon-Jeronimo and Florez-Lopez (2018) has shown that resource control positively and significantly influences aggregation only in the purchasing model. Conversion behavior is driven not only by proactive customer decisions but also by involuntary factors that are not related to proactive customer decisions (Roos 1999). Opportunistic behaviors of customers, once not effectively controlled, will cause many negative impacts and influence customers' decisions to choose banking services. In Vietnam, how is the relationship between opportunistic behaviors and conversion behavior in service usage shown? To see this clearly, the following hypothesis is proposed:

Hypothesis 5 (H5). Opportunistic behaviors positively affect conversion behavior in service use of individual customers at commercial banks in Vietnam.

\subsubsection{Brand Equity and Loyalty}

According to Aaker (1991), the value of a brand is achieved by a high level of customer loyalty, brand awareness, perceived quality, along with certain associations with the brand and its products, and other assets such as patents, certified trademarks, and distribution channel relationships. Brand equity can enhance customer loyalty with a bank, especially in the retail banking industry, where quality cannot be accurately assessed prior to purchase (Nguyen and LeBlanc 1998). Creating a reputation and brand has a long-term effect in maintaining customer loyalty and attachment to the bank's products and services. In order to better examine the relationship and impact direction of brand equity on the loyalty of individual customers at commercial banks in Vietnam, the following hypothesis is proposed:

Hypothesis 6 (H6). Brand equity positively affects individual customer loyalty at commercial banks in Vietnam. 


\subsubsection{Loyalty and Conversion Behavior in Service Use}

Research by Mittal and Lassar (1998) has shown that there is a correlation between customer loyalty and bank conversion behavior, when customer loyalty increases, it will lead to fewer cases of customers switching the choice of bank services. A positive relationship between brand loyalty and consumers' brand associations is pivotal to strengthen brand resonance (Keller 2016; Saleem et al. 2017). Creating customer trust and loyalty is always the goal that bank administrators aim to maintain the number of customers, as well as create safe and effective promotion channels, stimulate growth of new customers' entry into banking services. With commercial banks in Vietnam, how is this relationship shown, the following hypothesis is proposed:

Hypothesis 7 (H7). Loyalty has a negative effect on conversion behavior in service use of individual customers at commercial banks in Vietnam.

\subsubsection{Competitive Advertising Effectiveness and Opportunistic Behaviors}

In an era of intense growth and intense competition, the advertising effect will widen the channels of communication between customers and financial intermediaries to boost both banks' and institutions' chances of success. Dunn (1995) argues that advertising plays an important role in attracting customers to business activities of enterprises, and maintaining customer density during the growth phase. In the realm of strong competition, brands use cues as signals to communicate brand-related information to trigger positive outcomes of purchase and loyalty (Alias and Rasdi 2015). The effectiveness in competitive advertising brings positive signals when influencing the psychology of trust and customer satisfaction, thereby gradually reducing the customer's self-serving behavior and individualism, which is a precursor to a healthy, efficient, and professional business environment. In order to test the relationship between competitive advertising effectiveness and opportunistic behaviors of individual customers at commercial banks in Vietnam, the following hypothesis is proposed:

Hypothesis 8 (H8). Competitive advertising effectiveness has a negative effect on opportunistic behaviors of individual customers at commercial banks in Vietnam.

\subsubsection{Loyalty and Opportunistic Behaviors}

In banking operations, customers are those who use products and services and generate revenue mainly for banks. If customers are not satisfied with the bank, they may take advantage to conduct actions for their own benefits, ignoring the recommended regulations of the bank and society. The studies of Ahrholdt et al. (2017); Rambocas et al. (2018) have shown the direct link between customer satisfaction and behavioral outcomes of loyalty, word of mouth and willingness to pay a price premium. Zeithaml et al. (1996) argue that identifying and satisfying customer needs, which results in improving customer loyalty, helps to improve and retain customers, and has a positive impact in reducing opportunistic behaviors, thereby improving business performance. In the context of commercial banks in Vietnam, in order to test the relationship and impact direction of loyalty on opportunistic behaviors of individual customers, the following hypothesis is proposed:

Hypothesis 9 (H9). Loyalty has a negative effect on opportunistic behaviors of individual customers at commercial banks in Vietnam. 


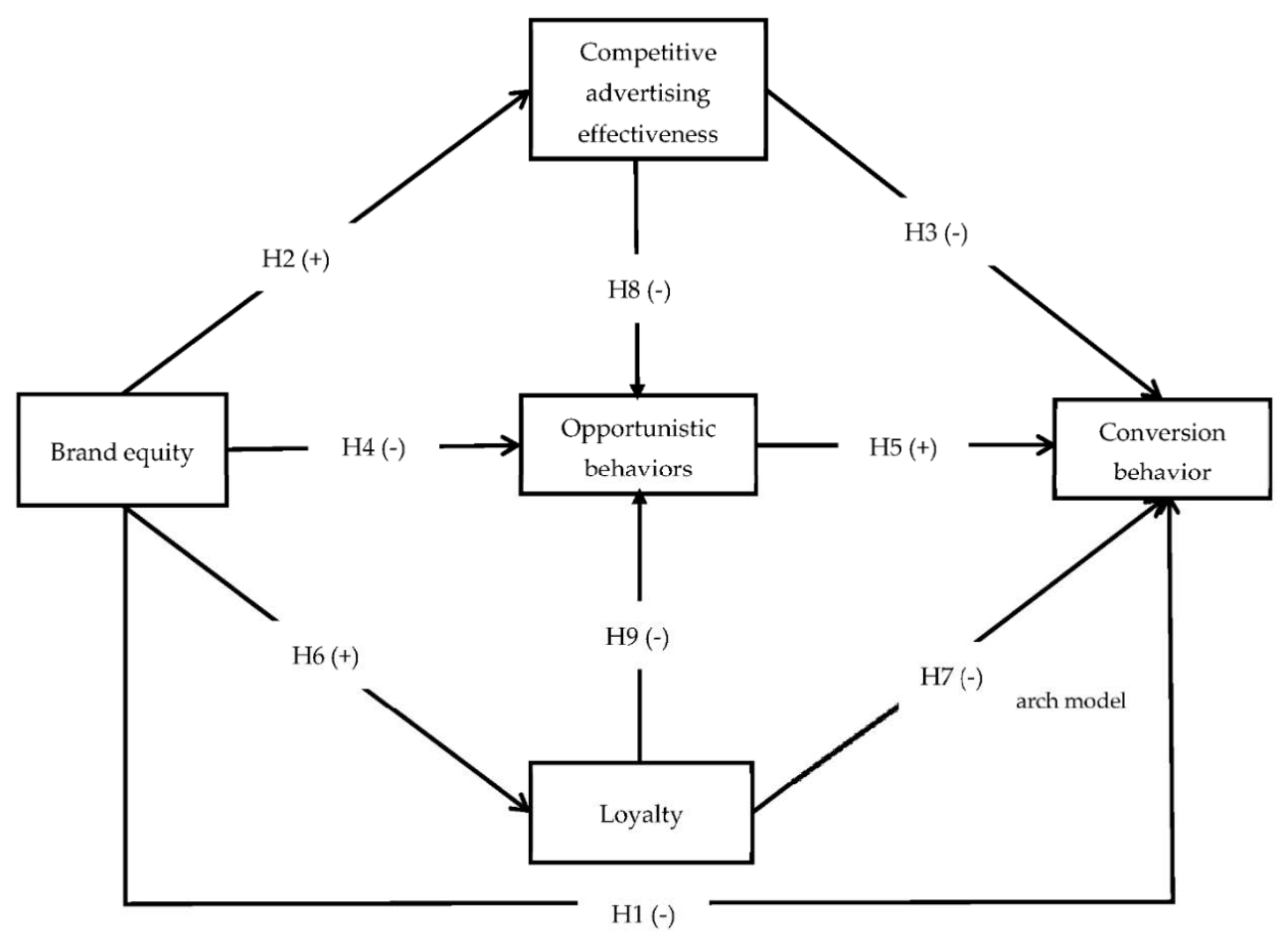

Figure 1. Research model.

\section{Research Methodology}

\subsection{Research Scale}

On the basis of theoretical overview and related studies, the article proposes a research model with the independent variable brand equity (see Figure 2). The intermediate variables are competitive advertising effectiveness, opportunistic behaviors, and loyalty. The target variable is conversion behavior in service usage of individual customers at commercial banks. The scale used in the study is a Likert scale with five levels (Strongly agree; Agree; Normal; Disagree; Strongly disagree). Indicators measuring variables are applied with adjustments in accordance with the study sample characteristics from previous studies (see Table 1).

Table 1. Origin of the scale of variables.

\begin{tabular}{|c|c|c|c|c|}
\hline No. & Variable & Ref. Code & $\begin{array}{c}\text { Number of } \\
\text { Observations }\end{array}$ & Scale Origin \\
\hline 1 & Brand equity & $\mathrm{BE}$ & 99 & Yoo et al. (2000) \\
\hline 2 & $\begin{array}{c}\text { Competitive advertising } \\
\text { effectiveness }\end{array}$ & CAE & 6 & Zhang et al. (2009) \\
\hline 3 & Opportunistic behaviors & OPB & 5 & Katsikeas et al. (2009) \\
\hline 4 & Loyalty & LOY & 6 & De Matos et al. (2009) \\
\hline 5 & Conversion behavior & CB & 5 & Boote (1998) \\
\hline
\end{tabular}

\subsection{Research Sample}

The research sample was selected by non-probability sampling method which is a form of convenience sampling. Data were collected through stratified sampling at Vietnamese commercial banks and branches are distributed in all three regions of the North, Central, and South such as Bank for Agriculture and Rural Development; Joint Stock Commercial Bank for Investment and Development; Joint Stock Commercial Bank for Industry and Trade; Ho Chi Minh City Development Joint Stock Commercial Bank ... The North includes banks and branches in Hanoi. The central region has bank branches concentrated in Nghe An, Ha Tinh, and Thanh Hoa. The South includes bank branches in Ho Chi Minh City. The 
investigation unit in the study is identified as individual customers of commercial banks. The sample size in the collection was 554 samples, including 241 male customers and 313 female customers distributed in groups of different ages. There were 89 customers under 20 years old, 134 between 20 and 30 years, 116 between 30 and 40 years, 118 between 40 and 50 years old, and 97 were 50 years old and above. The data collection process was conducted in two ways: face-to-face and online questionnaires. The number of online questionnaires collected is 302 , the number of usable questionnaires is 287. Directly, the number of questionnaires distributed is 500 , the number of questionnaires collected is 331 , the number of questionnaires that can be used is 267 . The total number of valid questionnaires used for analysis was 554. According to the study of Hair et al. (1998) for the reference of the expected sample size, the minimum sample size is 5 times the total number of observed variables. With the number of observations in the article is 31 , the research scale includes 554 samples meets the analysis requirements. The data collection completion period is from February 2021 to May 2021.

\subsection{Data Processing}

Research was conducted using quantitative methods. After data collection and cleaning, it is processed through SPSS and AMOS programs. First, evaluate the reliability of the scale with the required Cronbach's Alpha value $>0.7$. Next, research on exploratory factor analysis (EFA) to determine "converging value" and "distinguishing value of the scale" and with the requirement of Factor loading $>0.5$; KMO coefficient $>=0.5$ and $<=1$; Sig value $<0.05$, and the percentage of variance extracted $>50 \%$. After that, AMOS software is used to evaluate the suitability of the research model through CFA (Confirmatory Factor Analysis) test and finally test the research hypotheses by analyzing the SEM linear structure model with the requirements of chi-square/df index <3 (Hair et al. 1998); GFI, TLI, CFI > 0.9 (Segars and Grover 1993); RMSEA < 0.05 (Taylor et al. 1993).

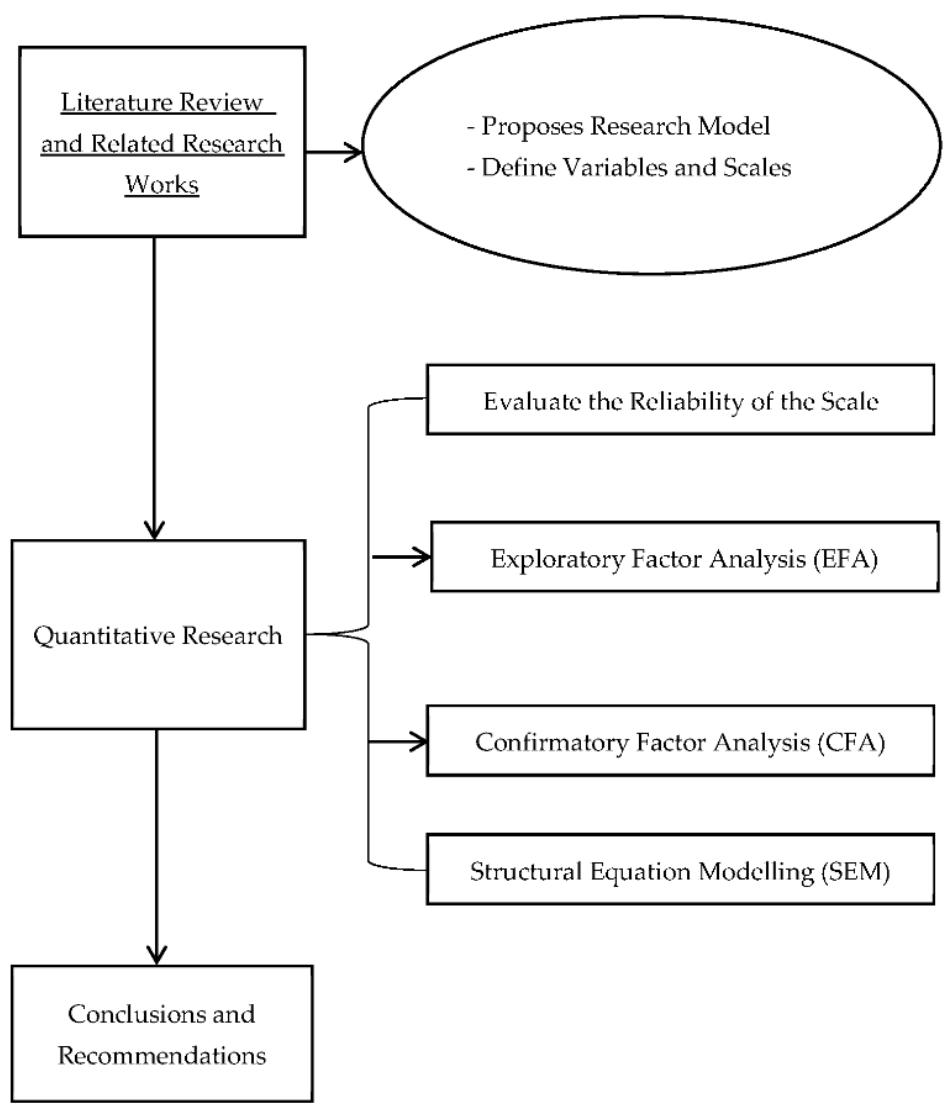

Figure 2. Proposed research structure. 


\section{Research Results and Discussion}

\subsection{Verify the Reliability of the Scale}

The analysis results of Cronbach's Alpha test show the reliability of the scale used in the analysis when the Cronbach's Alpha coefficients of all variables are $>0.7$. However, the BE6 indicator has a Cronbach's Alpha if Item Delete coefficient of 0.945 which is larger than the Cronbach's Alpha coefficient of the BE variable (0.941). Therefore, in order to increase the relevance of the scale, the study removed this indicator (see Table 2).

Table 2. Evaluation of the reliability of the scale through Cronbach's Alpha's coefficient.

\begin{tabular}{cccc}
\hline No. & Variable & Ref. Code & Cronbach's Alpha \\
\hline 1 & Brand equity & BE & 0.945 \\
2 & Competitive advertising effectiveness & CAE & 0.926 \\
3 & Opportunistic behaviors & OPB & 0.902 \\
4 & Loyalty & LOY & 0.882 \\
5 & Conversion behavior & CB & 0.872 \\
\hline
\end{tabular}

\subsection{EFA Analysis}

After testing the appropriateness of the scale, the study conducted an exploratory factor analysis (EFA) for both the independent, intermediate, and dependent variables. The results show that the data is eligible for analysis because it has factor loading coefficients $>0.5$ and satisfies two conditions: "Convergence value" (observed variables converge on the same factor) and "Convergence value" and "discriminant value" (observed variables belonging to one factor are distinguished from another) (see Table 3).

Table 3. Result of exploratory factor analysis EFA.

\begin{tabular}{cccccc}
\hline EFA Analysis & KMO's Coefficient & $p$-Value & $\begin{array}{c}\text { Average Variance } \\
\text { Extracted }\end{array}$ & Factor Loading & Conclusion \\
\hline $\begin{array}{c}\text { Independent variables and } \\
\text { intermediate variables }\end{array}$ & 0.948 & 0.000 & 70.757 & All are $>0.5$ & $\begin{array}{c}\text { Ensure analysis } \\
\text { requirements }\end{array}$ \\
\hline Dependent variable & 0.858 & 0.000 & 66.429 & All are $>0.5$ & $\begin{array}{c}\text { Ensure analysis } \\
\text { requirements }\end{array}$ \\
\hline
\end{tabular}

\subsection{CFA Analysis}

The results show the fit of the measurement model. Chi-square index $=856.442$, $\mathrm{df}=395, \mathrm{Chi}-$ square $/ \mathrm{df}=2.168(<3), p=0.000, \mathrm{GFI}=0.906(>0.9), \mathrm{TLI}=0.957(>0.9)$, $\mathrm{CFI}=0.961(>0.9), \mathrm{RMSEA}=0.046(<0.05)$.

\subsection{SEM Linear Structural Model Analysis}

Analyzing the SEM model for the research model, we found that the indexes were satisfactory. Specifically, Chi-square $=878.986, \mathrm{df}=396$, Chi-square $/ \mathrm{df}=2.220(<3)$ $p=0.000, \mathrm{GFI}=0.904(>0.9), \mathrm{TLI}=0.955(>0.9), \mathrm{CFI}=0.959(>0.9), \mathrm{RMSEA}=0.047(<0.05)$ (see Figure 3).

The results of the estimation of the relationships in the model show that the research model is appropriate. Except for hypothesis $\mathrm{H} 5$, all the remaining hypotheses are accepted with significance level $p<0.05$.

Specifically, hypothesis $\mathrm{H} 1$ is accepted with significance level $p<0.05$ and regression weight is $-0.294(<0)$. Therefore, it can be concluded that brand equity has a negative impact on conversion behavior in service use of individual customers at commercial banks in Vietnam. This result corresponds to the studies of Zeithaml et al. (1996); Berry (2000); Camerer and Weigelt (1988); Wang et al. (2003), etc. 


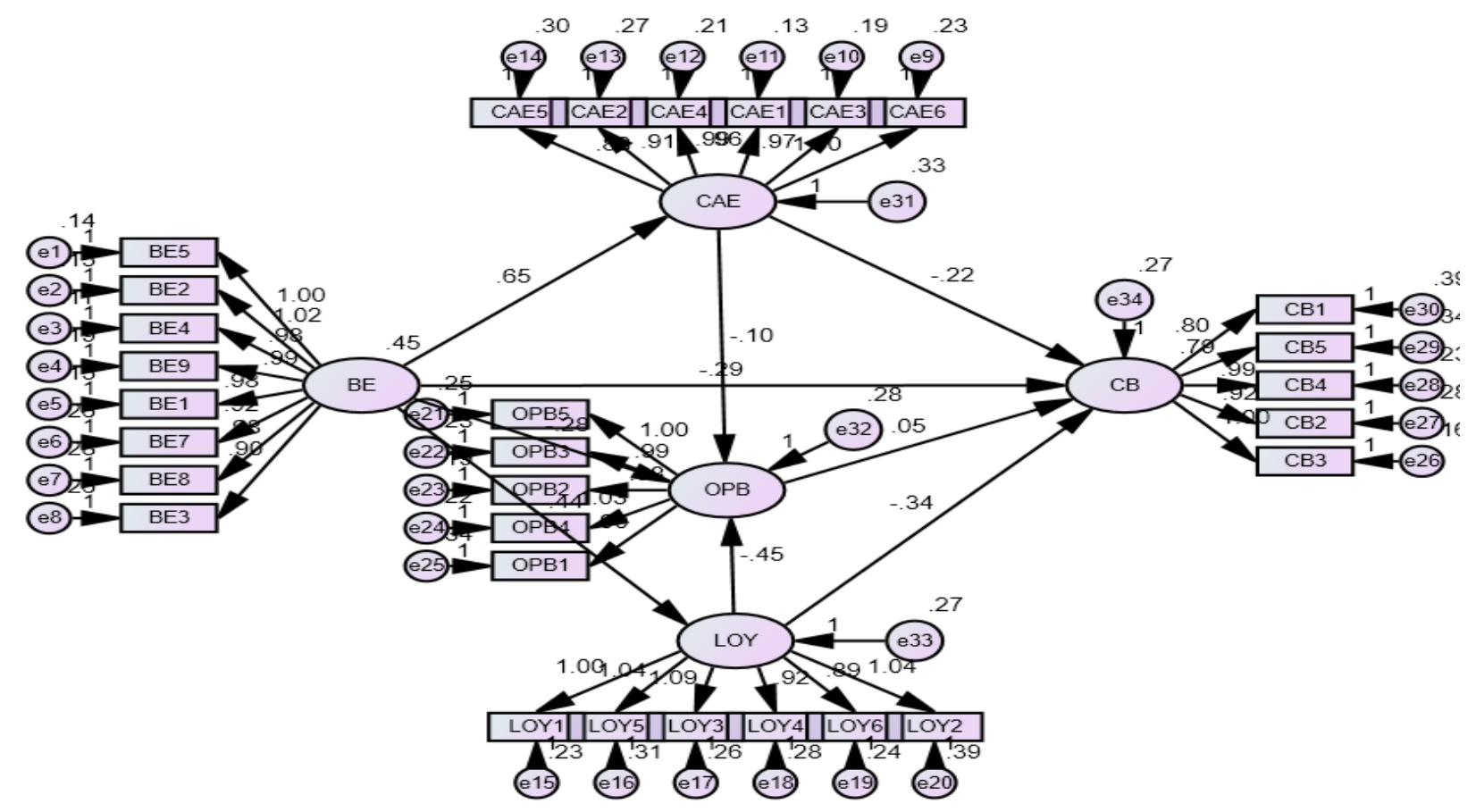

Figure 3. SEM model analysis.

Hypothesis $\mathrm{H} 2$ and $\mathrm{H} 3$ are accepted with significance level $<0.05$. At the same time, with a regression of $0.652(>0)$, the research results show that brand equity has a positive impact on the competitive advertising effectiveness of commercial banks. While, with a regression weight of -0.218 , it can be concluded that competitive advertising effectiveness has a negative impact on conversion behavior in service use of individual customers at commercial banks in Vietnam. These results reflect the work of Barney (1991); Vendelo (1998); Chakravarty et al. (2004); Davies (1996); Cengiz et al. (2007); Beckett et al. (2000), etc.

With the $\mathrm{H} 4$ and $\mathrm{H} 5$ hypotheses examining the impact of brand equity on opportunistic behaviors and the impact of opportunistic behaviors on conversion behavior in the use of personal banking services at commercial banks in Vietnam. Research results show that, with significance $<0.05$ and regression weight $-0.277(<0)$, hypothesis $\mathrm{H} 4$ is accepted. Therefore, it can be concluded that brand equity has the negative impact on the use of personal customer services at commercial banks. This result reflects the work of Balmer and Stovig (1997), etc. Meanwhile, with a significance of $0.343(>0.05)$, the study rejects the H5 hypothesis. That is, there is no impact of opportunistic behaviors on conversion behavior in the use of services by individual customers at commercial banks in Vietnam. This result shows that, for the vast majority of individual customers, conversion decisions in the use of their banking services are rarely influenced by the opportunistic behavior of individuals. It also shows the remarkable efforts of banks in the process of tightening inspections, strictly managing the service activities implemented, and showing the correct awareness and progress of customers in the decision-making process related to the use of commercial banking products and services.

Similarly, with a meaning of $p<0.05$ and a regression weight of $0.441(>0)$ and -0.335 $(<0), \mathrm{H} 6$ and $\mathrm{H7}$ hypotheses are accepted, respectively. It means that brand value has a positive impact on individual customers' loyalty to commercial banks. Meanwhile, loyalty has the negative impact on the use of personal banking at commercial banks in Vietnam. These results also correspond to the work of Aaker (1991); Nguyen and LeBlanc (1998); Mittal and Lassar (1998), etc.

Thus, by dismissing the $\mathrm{H} 5$ hypothesis, while accepting all the remaining hypotheses, the results of the study showed that the bank's brand equity had a negative impact on the use of personal customer service. At the same time, the findings showed the contribution of this study in proving the intermediary role of competitive advertising effectiveness and 
loyalty of customers in the relationship between brand equity and conversion behavior in the use of services of individual customers at commercial banks (see Table 4).

Table 4. Result of SEM analysis for relationships in the model.

\begin{tabular}{ccccccc}
\hline Hypothesis & Relationship & Weight & S.E. & C.R. & $p$ & Conclusion \\
\hline H1 & CB <- BE & -0.294 & 0.057 & -5.135 & 0.000 & Accept \\
H2 & CAE <- BE & 0.652 & 0.046 & 14.168 & 0.000 & Accept \\
H3 & CB <- CAE & -0.218 & 0.047 & -4.623 & 0.000 & Accept \\
H4 & OPB <- BE & -0.277 & 0.056 & -4.939 & 0.000 & Accept \\
H5 & CB <- OPB & 0.049 & 0.051 & 0.948 & 0.343 & Reject \\
H6 & LOY <- BE & 0.441 & 0.041 & 10.746 & 0.000 & Accept \\
H7 & CB <- LOY & -0.335 & 0.059 & -5.691 & 0.000 & Accept \\
H8 & OPB <- CAE & -0.105 & 0.047 & -2.247 & 0.025 & Accept \\
H9 & OPB <- LOY & -0.446 & 0.055 & -8.055 & 0.000 & Accept \\
\hline
\end{tabular}

In addition, H8, H9 hypotheses examine the impact of competitive advertising effectiveness and loyalty factors on conversion behavior in the use of personal customer services at commercial banks in Vietnam. The results of the study show that hypotheses are also accepted with a significance $p<0.05$ and a regression weight of -0.105 and -0.446 $(<0)$. This suggests that both advertising effectiveness and loyalty have a negative impact on the behavior of individual customers at commercial banks. These results correspond to the work of Dunn (1995); Zeithaml et al. (1996), etc.

\subsection{Descriptive Statistical Analysis}

As such, research has pointed out the importance of brand equity banking to the use of personal banking services at commercial banks in Vietnam. In addition, in order to relate and see the real manifestation of these factors, the study conducts a descriptive statistical analysis, determining the average value of variables included in the model.

The results showed that, with a value of 3.7738, the highest of all factors, loyalty of individual customers to commercial banks in Vietnam is highly appreciated. This shows that not only banks have been making the right and reasonable policies in their commitment to customers and implementing services, but also they show the progressive awareness of the vast majority of individual customers in decisions related to the use of the bank's products and services.

In addition, with the lowest of all factors included in the model (2.1123), it can be seen that conversion behavior in the use of personal customer services is being quite well controlled at commercial banks in Vietnam. Many banks today, with policies of interest, customer care, organizing many customer-care programs, annual customer conferences, etc., are creating positive effect on the part of customers. From there, building trust, having a great effect in building and developing brands and trusts of commercial banks. However, it is an undesirable factor, so in the near future, in order to further minimize the situation of customers leaving, banks still need more effective solutions in policy commitments and promise to implement their commitments earnestly (see Table 5).

Table 5. Statistical analysis results describing the value of variables.

\begin{tabular}{cccccc}
\hline Variable & N & Min & Max & Mean & Std. Deviation \\
\hline BE & 554 & 1.00 & 5.00 & 3.7477 & 0.66646 \\
CAE & 554 & 1.00 & 5.00 & 3.6173 & 0.70922 \\
OPB & 554 & 1.00 & 5.00 & 2.5188 & 0.71094 \\
LOY & 554 & 1.33 & 5.00 & 3.7738 & 0.63673 \\
CB & 554 & 1.00 & 5.00 & 2.1123 & 0.67325 \\
\hline
\end{tabular}




\section{Conclusions and Recommendations}

The study aims to establish a model and examine the direct and indirect impact of brand equity on conversion behavior in the use of personal banking services at commercial banks in Vietnam. The results of the study show that the bank's brand equity has a negative impact on the use of personal customer services. In addition, the study also demonstrated that competitive advertising effectiveness and loyalty both have the negative impact on the behavior of individual customers at commercial banks. The findings of this study have made a theoretical and practical contribution, demonstrating the importance and impact of brand equity on personal customer service usage, as well as the intermediary role of competitive advertising effectiveness and loyalty factors in this relationship. In practical terms, the research results help managers get more supporting solutions to limit the commercial banks' customers conversion behaviors.

Besides those contributions, the research also has certain limitations. With convenient sampling as a limitation of the study, it is possible to reduce the ability to control the representativeness of the sample. At the same time, the research context is also limited to commercial banks in Vietnam. With the results achieved, the paper opens up some possible prospective for further research conducted in many countries of the region and in the world.

Based on the results of the study, the author proposes a number of recommendations to limit customers' conversion of banks and personal services.

Firstly, regarding brand equity, bank managers must find ways to encourage the development of trust between customers and banks to eventually lead to loyalty. In addition to providing timely and accurate service, managers should encourage their employees to communicate with customers in which appropriate manners that can inspire their trust should be shown. In addition, banks need to have a well-informed and effective communication plan, which is conducted by relying on reputable communication channels.

Secondly, concerning competitive advertising effectiveness, the bank needs to strengthen its advertising measures to strengthen its competitiveness, which requires a variety of advertising methods to target different groups of customers. Managers should also develop strategies to strengthen communication channels between customers and banks.

Third, in regard with customer behaviors, the bank needs to have strict control over its service business. At the same time, the bank also needs to regularly organize customer's promotion programs, guide customers in the process of using services, have reasonable propaganda solutions to minimize personal redemption acts on the part of customers.

Fourthly, in terms of customer loyalty, banks need to research, build customer-specific programs, and provide customers with high-quality products / services. The banks need to have more customer-oriented support to build and maintain long-term relationships with them.

Funding: This research received no external funding.

Institutional Review Board Statement: Not applicable.

Informed Consent Statement: Not applicable.

Data Availability Statement: Not applicable.

Conflicts of Interest: The author declare no conflict of interest.

\section{References}

Aaker, David A. 1991. Managing Brand Equity. New York: Free Press.

Ahrholdt, Dennis C., Siegfried P. Gudergan, and Christian M. Ringle. 2017. Enhancing service loyalty: The roles of delight, satisfaction, and service quality. Journal of Travel Research 56: 436-50. [CrossRef]

Alias, Mazni, and Roziah M. Rasdi. 2015. Organizational Predictors of Workplace Deviance among Support Staff. Social and Behavioral Sciences 172: 126-33. [CrossRef]

Ansary, Amin, and Nik M. Hazrul Nik Hashim. 2018. Brand image and equity: The mediating role of brand equity drivers and moderating effects of product type and word of mouth. Review of Managerial Science 12: 969-1002. [CrossRef] 
Balmer, John M., and Snorre Stovig. 1997. Corporate identity and private banking: A review and case study. International Journal of Bank Marketing 15: 169-84. [CrossRef]

Barney, Jay. 1991. Firm resources and sustained competitive advantage. Journal of Management 17: 99-120. [CrossRef]

Barr, Greg. 2009. Study: Reputation, products key for banks. Houston Business Journal. May 11. Available online: http://www. bizjournals.com/houston/stories/2009/05/11/daily7.html (accessed on 1 July 2021).

Beckett, Antony, Paul Hewer, and Barry Howcroft. 2000. An exposition of consumer behaviour in the financial services industry. The International Journal of Bank Marketing 18: 15-26. [CrossRef]

Berry, Leonard L. 2000. Cultivating Service Brand Equity. Journal of the Academy of Marketing Science 28: 128-37. [CrossRef]

Boateng, Sheena L. 2019. Online relationship marketing and customer loyalty: A signaling theory perspective. International Journal of Bank Marketing 37: 226-40. [CrossRef]

Bolton, Ruth N., and Tina M. Bronkhurst. 1995. The Relationship Between Customer Complaints to the Firm and Subsequent Exit Behavior. Advances in Consumer Research 22: 94-100.

Boote, Jonathan. 1998. Towards a comprehensive taxonomy and model of consumer complaining behavior. Journal of Consume Satisfaction, Dissatisfaction and Complaining Behaviour 11: 140-51.

Camerer, Colin, and Keith Weigelt. 1988. Experimental Tests of a Sequential Equilibrium Reputation Model. Econometrica 56: 1-36. [CrossRef]

Cengiz, Ekrem, Hasan Ayyildiz, and Bunyamin Er. 2007. Effects of image and adverting efficiency on customer loyalty and antecedents of loyalty: Turkish banks sample. Banks and Bank Systems 2: 56-80.

Chakravarty, Sugato, Richard Feinberg, and Rhee Eun Y. 2004. Relationships and Individuals' bank switching behavior. Journal of Economic Psychology 25: 501-27. [CrossRef]

Chaudhuri, Arjun. 1999. The Effects of Brand Attitudes and Brand Loyalty on Brand Performance. European Advances in Consumer Research 4: 276.

Datta, Hannes, Kusum L. Ailawadi, and Harald J. Van Heerde. 2017. How Well Does Consumer-Based Brand Equity Align with Sales-Based Brand Equity and Marketing-Mix Response? Journal of Marketing 81: 1-20. [CrossRef]

Davies, Mark. 1996. Image problems with financial services: Some consideration for improvement. Management Decision 34: 64-71. [CrossRef]

De Matos, Celso Augusto, Jorge Luiz Henrique, and Fernando De Rosa. 2009. The different roles of switching costs on the satisfactionloyalty relationship. International Journal of Bank Marketing 27: 506-20. [CrossRef]

Duncan, Elizabeth, and Greg Elliot. 2002. Customer service quality and financial performance among Australian retail financial institution. Journal of Financial Services Marketing 7: 25-41. [CrossRef]

Dunn, Douglas. 1995. Advertising and Promotion. Advertising and Promotion. Direct Farm Marketing and Tourism Handbook. Tucson: The University of Arizona.

Ennew, Christine T., and Martin R. Binks. 1996. The Impact of Service Quality and Service Characteristics on Customer Retention: Small Business and Their Banks in The UK. British Journal of Management 7: 219-30. [CrossRef]

Filieri, Raffaele, Zhibin Lin, Antone Simona D., and Elena Chatzopoulou. 2019. A cultural approach to brand equity: The role of brand mianzi and brand popularity in China. Journal of Brand Management 26: 376-94. [CrossRef]

Garland, Rosemarie. 2002. Estimating customer defection in personal retail banking. The International Journal of Bank Marketing 20: 317-25. [CrossRef]

Gerrard, Philip, and J. Barton Cunningham. 2004. Consumer switching behaviour in the Asia banking market. The Journal of Service Marketing 18: 215-23. [CrossRef]

Hair, Joseph F., Rolph E. Anderson, Ronald L. Tatham, and William C. Black. 1998. Multivariate Data Analysis, 5th ed. Upper Saddle River: Prentice Hall.

Igbudu, Nicholas, Zanete Garanti, and Temitope Popoola. 2018. Enhancing Bank Loyalty through Sustainable Banking Practices: The Mediating Effect of Corporate Image. Sustainability 10: 4050. [CrossRef]

Javalgi, Rajshekhar G., Griffith David A., and White D. Steven. 1989. An Empirical Examination of Factors Influencing the Internationalization of Service Firms. Journal of Services Marketing 17: 185-201. [CrossRef]

Ramon-Jeronimo, Juan Manuel, and Raquel Florez-Lopez. 2018. What Makes Management Control Information Useful in BuyerSupplier Relationships? Journal of Risk and Financial Management 11: 31. [CrossRef]

Karatepe, Osman M., Anastasia Ozturk, and Taegoo Terry Kim. 2019. Servant leadership, organisational trust, and bank employee outcomes. The Service Industries Journal 39: 86-108. [CrossRef]

Kashif, Muhammad, Samsi S. Zakiah Melatu, and Sarifuddin Syamsulang. 2015. Brand equity of Lahore Fort as a tourism destination brand. Revista de Administracao de Empresas 55: 432-43. [CrossRef]

Katsikeas, Constantine S., Dionysis Skarmeas, and Daniel C. Bello. 2009. Developing successful trust-Based international exchande relationships. Journal of International Business Studies 40: 132-55. [CrossRef]

Keaveney, Susan M., and Madhavan Parthasarathy. 2001. Customer Switching Behavior in Online Services: An Exploratory Study of the Role of Selected Attitudinal, Behavioral, and Demographic Factors. Journal of the Academy of Marketing Science 29: 374-90. [CrossRef]

Keller, Kevin L. 2016. Reflections on customer-based brand equity: Perspectives, progress, and priorities. AMS Review 6: 1-16. [CrossRef] 
Keller, Kevin Lane. 1998. Strategic Brand Management. Upper Saddle River: Prentice Hall.

Khirallah, Kathleen. 2005. Customer Loyalty in Retail Banks: Time to Move Beyond Simple Programs or a Product Orientation. View Point Issue 127. New York: Tower Group.

Klapdor, Sebastian, Eva Anderl, Jan H. Schumann, and Florian Wangenheim. 2015. How to Use Multichannel Behavior To Predict Online Conversions Behavior Patterns across Online Channels Inform Strategies for Turning Users Into Paying Customers. Journal of Advertising Research 55: 433-42. [CrossRef]

Ko, Changsuk, Mark H. Haney, and Gukseong Lee. 2018. Effects of ethical leadership and formal control systems on employee opportunistic behavior in China. Benchmarking 25: 1350-62. [CrossRef]

Leone, Robert P., Vithala R. Rao, Anita Luo Pawluk, and Leigh McAlister. 2006. Linking Brand Equity to Customer Equity. Journal of Service Research 9: 125-38. [CrossRef]

Merrilees, Bill. 2017. Experience-centric branding: Challenges and advancing a new mantra for corporate brand governance. Journal of Brand Management 24: 1-13. [CrossRef]

Mittal, Banwari, and Walfried M. Lassar. 1998. Why do customers switch? The dynamics of satisfaction versus Loyalty. The Journal of Services Marketing 12: 177-94. [CrossRef]

Morgan, Robert M., and Shelby D. Hunt. 1994. The Commitment-trust theory of relationship marketing. Journal of Marketing 58: 20-38. [CrossRef]

Nguyen, Hoai Nam, Quoc Hoi Le, Quang Bach Tran, Thi Hoang Mai Tran, Thi Hai Yen Nguyen, and Thi Thuy Quynh Nguyen. 2020. The Impact of Organizational Commitment on Employee Motivation: A Study in Vietnamese Enterprises. Journal of Asian Finance, Economics and Business 7: 439-47. [CrossRef]

Nguyen, Nha, and Gaston LeBlanc. 1998. The mediating role of corporate image on customers' retention decisions: An investigation in financial services. International Journal of Bank Marketing 16: 52-65. [CrossRef]

Rambocas, Meena, Vishnu M. Kirpalani, and Errol Simms. 2018. Brand equity and customer behavioral intentions: A mediated moderated model. International Journal of Bank Marketing 36: 19-40. [CrossRef]

Reichheld, Frederick F. 1996. The Loyalty Effect. Boston: Harvard Business School Press.

Roos, Inger. 1999. Switching processes in customer relationships. Journal of Service Research 2: 376-93. [CrossRef]

Rust, Roland T., Zahorik Anthony J., and Keiningham Timothy L. 1996. Services Marketing. New York: Harper Collins College Publishers.

Saleem, Muhammad A., Sadaf Zahra, and Asif Yaseen. 2017. Impact of service quality and trust on repurchase intentions-The case of Pakistan airline industry. Asia Pacific Journal of Marketing and Logistics 29: 1136-59. [CrossRef]

Segars, Albert H., and Varun Grover. 1993. Re-Examining Perceived Ease of Use and Usefulness: A Confirmatory Factor Analysis. MIS Quarterly 17: 517-25. [CrossRef]

Stewart, Kate. 1998. An exploration of customer exit in retail banking. International Journal of Bank Marketing 16: 6-14. [CrossRef]

Suhartanto, Dwi, Brendan T. Chen, Zurinawati Mohi, and Adila Sosianika. 2018. Exploring loyalty to specialty foods among tourists and residents. British Food Journal 120: 1120-31. [CrossRef]

Taylor, Philip D., Lenore Fahrig, Kringen Henein, and Gray Merriam. 1993. Connectivity is a vital element of landscape structure. Nordic Society Oikos 68: 571-73. [CrossRef]

Vendelo, Morten T. 1998. Narrating Corporate Reputation: Becoming Legitimate Through Storytelling. International Studies of Management and Organization 28: 120-37. [CrossRef]

Wang, Yi S., Yu M. Wang, Hsin H. Lin, and Tzung I. Tang. 2003. Determinants of User Acceptance of Internet Banking: An Empirical Study. International Journal of Service Industry Management 14: 501-19. [CrossRef]

Yoo, Boonghee, and Naveen Donthu. 2001. Developing and Validating a Multidimensional Consumer-Based Brand Equity Scale. Journal of Business Research 52: 1-14. [CrossRef]

Yoo, Boonghee, Naveen Donthu, and Sungho Lee. 2000. An Examination of Selected Marketing Mix Elements and Brand Equity. Journal of the Academy of Marketing Science 28: 195-211. [CrossRef]

Zeithaml, Valarie A., Berry Leonard L., and Parasuraman A. 1996. The Behavioral Consequences of Service Quality. Journal of Marketing 60: 31-46. [CrossRef]

Zhang, Li, Yuan Wei, and Hong Wang. 2009. Government informatization: A case study. Systems Research and Behavioral Science 26: 169-90. [CrossRef] 